\title{
Segmentation of Trek and Trall Race RunNers as Tourists
}

\section{Abstract:}

This paper seeks to supplement the theory of sports marketing with additional knowledge on the participants in trek and trail races, provide basis for better understanding of their motives and behavior. The research instrument is a questionnaire consisting of 30questions where the first part concerns with behavior at races; the second part consists of statements about the motives and the third part of descriptive questions. There were 194 participants who were interviewed by an online survey. The statistical analysis was conducted using factor analysis and cluster analysis.

\section{Keywords:}

Five different factors / types of motivation and behavior of trek and trail race runners were extracted. Cluster analysis was also conducted and three cluster solutions were retained. Implications for marketing practice, limitations of the research and recommendations for future research were also given.

Small-scale sporting events; Trek and trail races; Active sport tourists; Factor analysis; Cluster analysis

\section{Author's data:}

${ }^{1}$ dr.sc. Ivana Tonković Pražic, Veleučilišste Nikola Tesla u Gospiću, B. I . Karlovića 16, Gospić, itonkovic-prazic@velegs-nikolatesla.hr

${ }^{2}$ Marko Pražič, dipl.oec., HEP Group, Kaniška 31, Gospič, marko.prazic@gmail. com

${ }^{3}$ dr.sc. Kristina Devčić, veleučilište Nikola Tesla u Gospiću, kdevcic@velegs-nikolatesla.hr

International Journal - VALLIS AUREA • Volume 7 • Number 1 • Croatia, June 2021 


\section{Introduction}

The potential of sport tourism is considerable, as many studies suggested, such as [1] , [2] and [3]. Some authors, such as [2] argue that travel related to sport and physical activity is one of the fastest growing segments of the tourism industry, which was confirmed by the increase in the number of tourists attracted by sporting events, [1] and [3]. Although mega-sporting events proved to attract many tourists and have a positive effect on the economy of a nation [4], small-scale sporting events in which tourists are more likely to be participants than the audience are becoming more prevalent [5], [6], [7].

The popularity of small-scale sporting events in the world, as well as in the Republic of Croatia, is expanding - for example, 529 registered participants from 23 countries at the 100 Miles of Istria race in 2014 increased to 2388 registered participants from 61 countries organized in 2019 [8]. Participation in such forms of active sport tourism arises from the need for a healthy life and enjoyment in nature, which are becoming an increasingly important part of modern life due to the trends of hightened concern for health, awareness of the need for nature protection and its importance to community, increase in the average income, etc. [9]. Some of the aforementioned needs of a modern man can also be successfully satisfied with a specific type of small-scale sporting event- trek and trail races, which include the need for recreation and spending time in pristine nature. Namely, unlike classic races, these types of races are organized in a natural environment, and it is desirable that the areas in which they are organized are disturbed by people as little as possible. Both types of races are pretty similar but there is one distinctive difference: unlike trail races, in trek races the race runners themselves choose the path they will go through, provided they navigate the given check points.

Apart from the benefits they provide for participants, the only goal of organizing a race is not just a sports competition, but such sporting events have proven to have a significant impact on the economic and social development of the regional and local community where they take place, such as [10], [11], [7], [12]. Some authors, like [13], [6] and [12] state that small-scale sporting events are the drivers of local community development and have significant potential for the local community through economic benefits, infrastructure development and season extension (for example, the Istria trek, which takes place every year at a different Istrian location outside of the summer season - in February]. In order to achieve those benefits, the organizers try to attract as many tourists as possible, who in the case of trek and trail races are prevalently the participants themselves, ie. race runners. Aside from the above mentioned, trek and trail races have a potential for further growth. Having all of the above in mind, tourism boards and small-scale sporting event organizers acknowledge trek and trail races' importance and choose to pursue strategies that will ensure them a favourable competitive position in order to reap the benefits. Among those strategies, segmentation stands out, because it affords the opportunity to understand the market 
and adapt the marketing strategies to homogenous groups - segments. Thus, in order to further our understanding of a specific group of active sport tourists - trek and trail race runners, the objective of this research was to extract factors of trek and trail runners' behavior and motivation and distinguishing distinct segments based on extracted factors. According to the objectives of the paper, two research hypotheses were set: considering the motives and behavior of participants in trek and trail races, it is possible to extract different factors of trek and trail race runners; and Segments of trek and trail race runners based on their motives and behavior can be distinguished.

In order to test the hypotheses, empirical research has been conducted. For the purpose of this research, the questionnaire was developed. Factor analysis was conducted to discover the underlying types of motives and behavior of trek and trail runners and then using the cluster analysis clusters of trek and trail runers were extracted.

\section{Review of Previous Research}

The analysis of relevant research dealing with small-scale sporting events pointed to the conclusion that papers were mostly descriptive and provided information about the event itself but not the explanations of active sport tourists' behavior and their motives [14]. For example, [15] argued that sport tourism research is dominated by event research, but the focus is rarely set on running activities in nature, and the author referred to the need to explore precisely this aspect of sport tourism more thoroughly. [16] argued that it was necessary to explore the subjective experiences and perceptions of participants in outdoor tourism events in order to fully understand them. However, while studies on various organized sporting events in nature did exist, research on trek and trail races was rare.

Some authors [[17] and [18]] found that the act of participating in a sporting event implies different meanings for the participant, such as adventure, experience, but also a number of personal meanings. Other relevant factors and motives for active sport tourists' participation in a small-scale sporting event were connected to their engagement in sports [19], self-actualization needs [20], nature-related travel [21], social aspect [22], [20], achievement [23], [24], environment and safety motives [25] etc. Since motives can stimulate an individual to take action [26], they are important to understanding and predicting a trek and trail race runners' behavior. However, although the aforementioned authors investigated motives of participants in some types of small-scale sporting events, most of them either investigated the motives of trek and trail races only partially or not at all. [27] argued that trek and trail race runners' niche has not been substantially researched despite its growing potential - its both economic and social impact on local communities, which is why this research aims to fulfill this gap in the knowledge on trek and trail race runners.

[27] pointed to the fact that it proved vital to investigate the motivations and behavior of bicycle tourists, since it would provide a sound basis for 
understanding and segmentation of this market niche. Therefore, it would also be necessary to investigate both the motives and behavior of trek and trail race runners as a basis for their segmentation.

\section{Research hypotheses}

Some relevant research on trail runners has been conducted that focused on different aspects of this specific type of sport tourism. There were papers dealing with the influence of trail running sport events on destinations where those events are organized [12], [28], the trail runners ecological impact [29], [30], the expenditures of trail runners [31], but some of the reasearch dealt with motivations of trail runners [32], [33], [34].

[34] compared ski tourers to trail runners and, although their research provides some important insights into the motivational factors of trail runners, emphasize the need to further investigate motives of sport tourists with other samples and destinations. [31] researched expenditure patterns of trail runners but also extracted seven motivational factors common to trail runners.

Based on findings of relevant authors, it can be presumed that motivational factors of trek and trail runners could be extracted, thus the following hypothesis is set:

H1: Considering the motives and behavior of participants in trek and trail races, it is possible to extract different factors of trek and trail race runners.
[2] recommended researching the profiles of active sports tourists that would not only include segmentation into participants and nonparticipants, but should also provide an understanding of differences between active sport tourists based on differences between them in terms of gender, disability, social class, race and their life cycle phase. In addition, destination marketers suggest utilizing market segmentation identification as a means and method to perform marketing research [27] to assist with event tourism design and formulation, since tourists from different backgrounds will react to different offerings and at different times [35].

There were several studies on active sport tourist segmentation based on their motivation, the samples included winter sport tourists [36], surfers [37], [38], bicycle tourists [27], climbers [39], [40], golfers [41], marathon runners [42] etc. [43] pointed to the need to segment the market of active sport tourists and conducted his research on a sample of amateur athletes participating in many different small-scale sporting events. The author succesfully extracted several factors of underlying motives and also differentiated segments of active sport tourists: tourismoriented, neutral, sport tourist enthusiasts and sport-oriented. Although the author successfully distinguished segments of active sport tourists, he did not differentiate active sport tourists based on the sport they chose to participate in, although tourists engaging in sports fishing differ substantially based on their motivations and behavior from trek or trail race runners. However, not even this author did not succesfully segment 
trek and trail race runners, leaving this question vet unanswered.

Based on all the above, the following research hypothesis is set:

H2: Segments of trek and trail race runners based on their motives and behavior can be distinguished.

\section{Research methodology}

\section{Questionnaire design}

The questionnaire consisted of 30 questions, which were divided into three thematic units. The first group consisted of 7 closed-ended questions (previous participation, the way of arrival to the race, amount spent, time spent in a destination...J. The second group of questions consisted of 17 statements about trek and trail races, and the answers were given according to the Likerts cale (1 - totally disagree / claim completely incorrect, 2 somewhat disagree / claim somewhat incorrect, 3 - neither agree or disagree, 4 - somewhat agree / claim is somewhat correct, 5 - completely agree / claim is completely correct]. The third group consisted of 6 descriptive questions (gender, date of birth, place of residence, level of education, average monthly family income and number of household members].

The questionnaire was developed for the purpose of this research. As no similar research had been found in the relevant literature, claims that covered the potential motives and behavior in trek and trail races were developed. Interviews with trek and trail race runners were conducted and relevant research describing participants in races and other related sporting events was consulted [10], [44], [43], [25], which served as the basis for statements in the questionnaire.

\section{Empirical analysis}

The survey was conducted in the summer of 2019 based on the developed questionnaire. In order to collect data for analysis, participant surveys based on recall methods were used by some authors, such as [45] and [46], and thus this method was applied also in this research. Respondents selected on the basis of a convenient sample were questioned on several trek and trail races that took place between June 2019 and September 2019. A total of 194 trek and trail race runners were questioned. Due to the incompleteness of the answers given, 16 respondents were removed from the analysis and further analysis was carried out on the data collected from a total of 178 respondents $[91,8 \%$ of the total respondents]. Demographics for the sample are illustrated in Table1.

\begin{tabular}{|r|r|r|r|r|r|}
\hline \multicolumn{2}{|c|}{$\begin{array}{c}\text { Demographic } \\
\text { Characteristics }\end{array}$} & N & $\%$ & Avg & S.D. \\
\hline Gender & Male & 78 & 55,68 & & \\
\hline Female & 98 & 44,31 & & \\
\hline Age & & & & 40,86 & 8,62 \\
\hline $20-29$ & 11 & 7,53 & & \\
\hline $30-39$ & 52 & 35,62 & & \\
\hline $40-49$ & 62 & 42,47 & & \\
\hline
\end{tabular}




\begin{tabular}{|c|c|c|c|c|}
\hline $\begin{array}{l}\text { Demographic } \\
\text { characteristics }\end{array}$ & $\mathbf{N}$ & $\%$ & Avg & S.D. \\
\hline $50-59$ & 16 & 10,96 & & \\
\hline $60-69$ & 5 & 3,42 & & \\
\hline Residence & & & & \\
\hline $\begin{array}{r}\text { Slavonija, Baranja } \\
\text { and Srijem }\end{array}$ & 13 & 7,34 & & \\
\hline Central Croatia & 114 & 64,41 & & \\
\hline Northern Adriatic & 27 & 15,25 & & \\
\hline Southern Adriatic & 23 & 13,00 & & \\
\hline Education degree & & & & \\
\hline High School & 42 & 23,60 & & \\
\hline College & 127 & 71,35 & & \\
\hline $\begin{array}{l}\text { Master's or } \\
\text { Doctorate Degree }\end{array}$ & 9 & 5,05 & & \\
\hline $\begin{array}{l}\text { Average Monthly } \\
\text { Family Income }\end{array}$ & & & & \\
\hline Up to 4000 HRK & 16 & 9,14 & & \\
\hline 4000-8000 HRK & 55 & 31,43 & & \\
\hline 8000-12000HRK & 47 & 26,86 & & \\
\hline $\begin{array}{r}\text { More than } 12000 \\
\text { HRK }\end{array}$ & 57 & 32,57 & & \\
\hline $\begin{array}{l}\text { Number of } \\
\text { Household } \\
\text { Members }\end{array}$ & & & 2,64 & 1,06 \\
\hline 1 & 28 & 17,95 & & \\
\hline
\end{tabular}

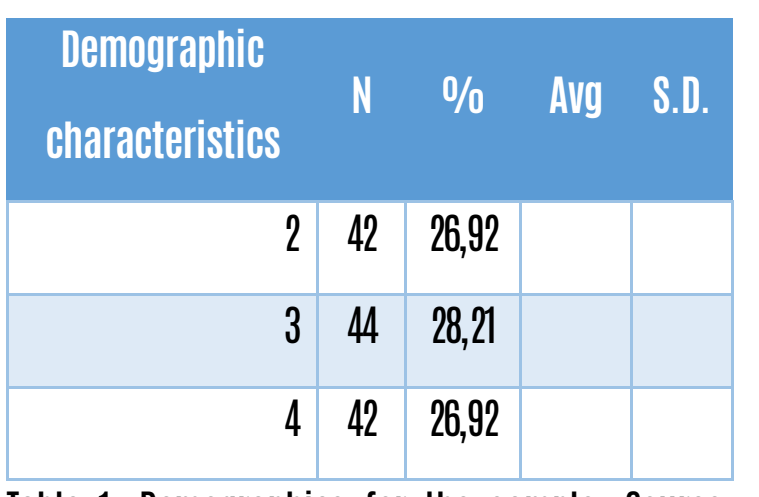

Table 1. Demographics for the sample. Source: authors' calculation.

\section{Research results}

Statistical analysis was performed using the SPSS program. In the first phase of the analysis, the reliability of the questionnare was examined. According to Cronbach Alpha coefficient, questionnare was reliable $[0,746]$ and had satisfactory internal consistency. The KaiserMeyer-Olkin test of adequacy of sampling was performed, obtaining the value of 0,890 which indicated that the sample used in the research was adeqaute, since it was larger than the cut-off point of 0,60 . Bartlett's test of sphericity $[742,034 ;$ $\mathrm{p}=0,000$ ) was also conducted, which indicated that the sample was appropriate for factor analysis. When conducting factor analysis, one wants to reduce a large number of observed variables to a smaller number of factors. In this research this method was considered appropriate because it allows to reduce the number of variables and discover the underlying types of motives and behavior. Exploratory factor analysis was performed using the principal components method. Five factors with eigenvalues greater than 1 were extracted and $59,112 \%$ of the total variance 
was explained. Varimax rotation was chosen. Extracted factors were named Tourist Offer, Personal Growth, Self-Fullfilment, Social Needs and New Experiences. Factor I, Tourist Offer, was most strongly related to the set of five variables which reffered to tourist elements of the races such as the destination attractions, concerts, excursions, sightseeing in the area, education by famous athletes, shows and performances. This factor contributed 21,762\% of the variance. Factor II, Personal Growth, was most strongly related to the set of three variables which ad the highest rating on overcoming challenges, sense of achievement, building confidence and advancing as a runner. This factor contributed $13,625 \%$ of the variance. Factor III, Self-fullfilment, was most strongly related to the set of four variables refering to proving oneself that one can do it, feeling happy, having fun, feeling healthier, feeling more mentally stable. This factor contribued $8,640 \%$ of the variance. Factor IV, Social Needs, was most strongly related to the set of three variables describing meeting other people, socializing with others, giving up Iuxuries to come to a race, coming to a race with family, teaching children the importance of doing sports. This factor contributed $7,871 \%$ of the variance. Finally, factor V, New Experiences, was most strongly related to the set of two variables reffering to first time participating and coming to a race out of curiosity. This factor contributed 7,214\% of the variance. The results of the factor analysis are shown in Table 2.

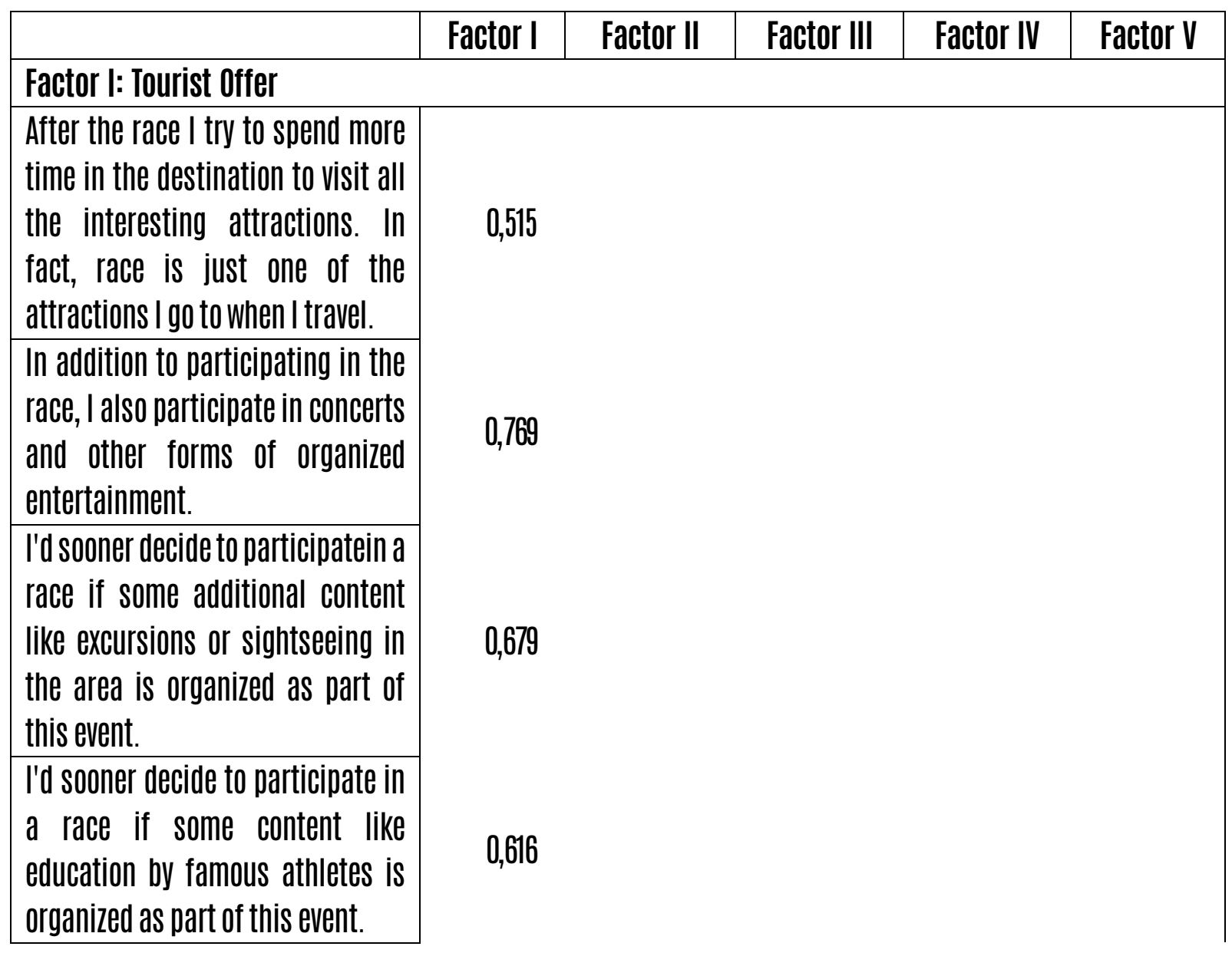

International Journal - VALLIS AUREA • Volume 7 • Number 1 • Croatia, June 2021 UDK 796.093.55:338.48-51; DOI 10.2507/IJVA.7.1.4.79 


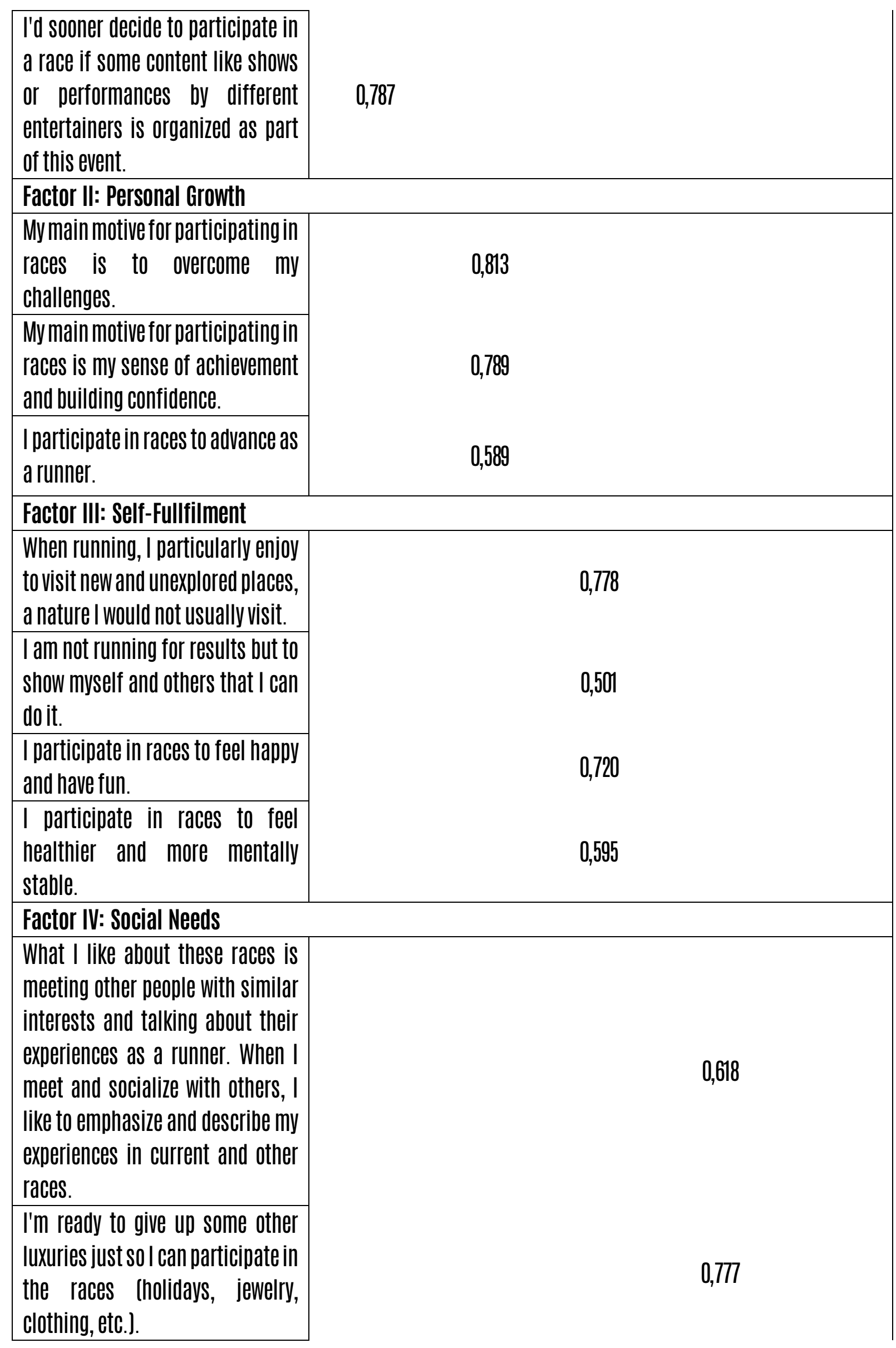


I came to the race with my family to show them what it looks like and to teach children the importance of doing sports.

\section{Factor V: New Experiences}

It was my first time participating in this kind of race, but I believe I 0,594 will come again.

I come to events like this just to see what it is like, out of curiosity.

I'm not an active runner, I just wanted to see what this event looks like.

\begin{tabular}{|l|c|c|c|c|c|}
\hline Cronbach Alpha & 0,739 & 0,708 & 0,614 & 0,569 & 0,465 \\
\hline Eigenvalue & 3,700 & 2,316 & 1,469 & 1,338 & 1,226 \\
\hline Variance [\%] & 21,762 & 13,625 & 8,640 & 7,871 & 7,214 \\
\hline Cumulative Variance [\%] & 21,762 & 35,387 & 44,027 & 51,898 & 59,112 \\
\hline
\end{tabular}

Table 2. Factors loadings for variables in factor analysis. Source: authors' calculation.

In order to segment trek and trail race runners cluster analysis was conducted. Since two-step cluster analysis suggested three clusters, K-means cluster analysis with a three-cluster solution was performed. To validate three given cluster solutions, one-way ANOVA clustered membership was performed to obtained factor scores. The results of $\mathrm{K}$-means cluster analysis are shown in Table 3.

\begin{tabular}{|l|c|c|c|c|c|}
\hline & $\begin{array}{c}\text { Personal } \\
\text { Growth } \\
\text { Oriented }\end{array}$ & $\begin{array}{c}\text { Self- } \\
\text { Fullfilment } \\
\text { Oriented }\end{array}$ & $\begin{array}{c}\text { Additional } \\
\text { content } \\
\text { Oriented }\end{array}$ & $\mathrm{F}$ & Sig \\
\hline Tourist Offer & $\mathbf{0 , 0 3 9 7 4}$ & $-0,60128$ & $\mathbf{0 , 4 4 3 5 9}$ & 16,151 & $\mathbf{0 , 0 0 0}$ \\
\hline Personal Growth & $\mathbf{0 , 3 2 9 9 6}$ & $-0,90924$ & $\mathbf{0 , 2 6 7 1 9}$ & 35,989 & 0,000 \\
\hline Self-Fullfilment & $-0,37072$ & $\mathbf{0 , 5 2 9 3 5}$ & $\mathbf{0 , 2 4 5 1 0}$ & $\mathbf{2 0 , 2 6 5}$ & $\mathbf{0 , 0 0 0}$ \\
\hline Social Needs & $-0,45790$ & $\mathbf{0 , 3 6 1 1 9}$ & $\mathbf{0 , 3 7 9 1 0}$ & 17,849 & $\mathbf{0 , 0 0 0}$ \\
\hline New Experiences & $-0,55088$ & $-0,10737$ & $\mathbf{1 , 0 1 8 1 2}$ & $\mathbf{7 0 , 0 2 9}$ & $\mathbf{0 , 0 0 0}$ \\
\hline
\end{tabular}

Table 3. K-means cluster analysis results. Source: authors' calculation

The first cluster, called Personal Growth Oriented, represented $48 \%$ of the sample and was characterized by high ratings for Personal Growth. This segment mostly consisted of trek and trail race runners who come from Central croatia and are middle-aged (40-50years old], come to races of this type at least ten times a year $[44 \%$ ] and mostly travel individually [56\%), arrive shortly 
before the race and leave immediately after it [55\%]. They try to minimize their costs, but in addition to the costs of travel and participation, they usually spend money on food, drinks and the like (58\%), which is usually less than 500 HRK $[59 \%$ ].

The second cluster, called Self-Fullfilment Oriented, represented $27 \%$ of the sample and was characterized by high ratings for Self-fullfilment. This segment mostly consisted of runners who come from Central Croatia and are middle-aged [40-50 years old], with a monthly family income of more than 12000 HRK (39\%). They come to these types of races at least ten times a year (400\%), mostly travel individually (52\%), use individual accommodation (42\%) and spend 500 to 1000 HRK per race $(46 \%)$.

The third cluster, called Additional Content Oriented, represented 25\% of the sample and valued Touristic Offer, Social Needs and New Experiences factors greater than other factors. This segment mostly consisted of runners who come from Central Croatia and are younger $330-40$ years old], with a monthly family income between 4000 and 8000 HRK (45\%). They participate in those races that are easiest for them to reach ffor financial reasons or proximity to the event) (43\%)], arrive mostly individually (64\%) the day before the race and stay until all race-related events are over [52\%]. Members of this segment also try to minimize costs, but in addition to travel and participation costs usually spend on food, drinks and the like (50\%), which is usually less than 500 HRK per race $(51 \%$ ].

\section{Discussion}

The results of the research pointed to several conclusions and provided answers to the research hypotheses raised. Firstly, factors of trek and trail race runners' motives and behavior were successfully extracted, thus confirming the first hypothesis. Five extracted factors were: Tourist offer, Personal Growth, Self-Fullfilment, Social Needs and New Experiences.

Based on the aforementioned factors, cluster analysis was conducted that resulted in three segments of trek and trail race runners, thus confirming the second hypothesis. Extracted segments were named Personal Growth oriented, Self-Fullfilment Oriented and Additional Content Oriented. Personal Growth Oriented members are driven by competition, their need to overcome their own challenges, but also their need to grow and evolve as runners. They come to the race to gain the sense of achievement and for building confidence. Respondents who are Self-Fullfilment Oriented indicated that their primary motives for participating centered around a desire to improve their health and feel happy. Members of this segment are also motivated to participate in order to show themselves and others that they can succeed. The third segment, Additional content Oriented, exhibits more interest in the festivities and touristic attractions than the other two segments. The members of this segment prefer satisfying their social needs by socializing with 
other participants and their own family at a race. This segment is also characterized by its members participating out of curiosity and not being a determined participant of these kind of smallscale sporting events.

Points on how to attract members of different segments to a trek or trail race can be made based on the results of the conducted research. Event organizers may choose to build their marketing strategies, plans and advertising appeals for Personal Growth Oriented segment, since they seem to be the largest segment of trek and trail race runners in Croatia. The marketing campaign attracting members of this segment should appeal to the competitive aspects of a race and promote the possibility for self-improvement. Relying on oneself to overcome obstacles and succeed in completing a challenge may prove to be efficient marketing appeals as well. The special offer for this segment should contain the courses and instructions on how to be a consistent and career trek and trail race runner.

When addressing the Self-Fulfilment Oriented segment, organizers should highlight the positive influences of a race on phisical and mental wellbeing of an individual. In building a marketing campaign using marketing appeals that promote health benefits would be advised. In addition, marketing campaigns should portrait the beautiful, calming and peaceful scenery one would encounter while on a race. The special offer for this segment should contain healthy local food and beverages options, and also courses on a healthier lifestyle.
If an organizer of a trek and trail race chooses to build a marketing campaign to attract members of the Additional Content Oriented, promotional material should include appeals to family life, by showing family members enjoying exploring nature and running together. Also, showing people having fun and hanging out during such events may prove to be encouraging to this segment. In addition, since they have proven to be interested in touristic elements of a race, organizers should cooperatewith local enterprises and tourist boards to develop and offer more attractive product choices and local sights visits designed for specific races. When marketing an event to this segment, organizers must acknowledge participants' desire to explore a destination's offerings by disseminating information pertaining to local attractions or activities that may enhance a consumer's overall visit. Since some members of this segment are not as familiarized with the trek and trail races, it could be advised to dispense information on the races themselves, the terrain and sport specificities, destination characteristics, advantages of participation in a race etc.

\section{Conclusion}

The aim of this paper was building on the literature of active sport tourists by analyzing the motives and behavior of trek and trail race runners and using them as a basis for their segmentation. The empirical research conducted on a sample of trek and trail race runners from the Republic of Croatia resulted in extracting five motivational and 
behavioral factors as well as three statistically significantly different segments, thus confirming the research hypotheses.

Despite the presented advantages of this research, it is possible and necessary to point out some of its disadvantages and limitations. Specifically, research was carried out on a smaller sample and future research should be conducted on a larger sample in order to obtain a more complete picture. Furthermore, a survey should be conducted on samples of trek and trail race runners from different countries to compare and ascertain a better understanding of trek and trail race runners as a specific niche of active sport tourists. In addition, the research instrument was adapted to the research presented, but it might not be applicable to different aspects of trek and trail race runners' research. Therefore, it can be recommended that the research instrument should be further enriched and adapted by adding specific questions or removing some claims as needed.

\section{References}

[1] Saayman, M. [2012]. An Introduction to Sports Tourism and Event Management, AFRICAN SUN MeDIA, Matieland, South Africa

[2] Gibson, H.J. (1998). Sport Tourism: A Critical Analysis of Research. Sport nagement Review, 1,1, $45-76$.

[3] Burgan, B.,\& Mules, I. (1992). Economic Impact of Sporting Events. Annuals of Tourism Research, $19,700-710$.
[4] Gratton, C., Dobson, N., \& Shibli, S. (2000). The economic importance of major sports events: A case-study of six events. Managing Leisure, 5, 1,1728.

[5] Gibson, H. J., Attle, S. P., \& Yiannakis, A. (2001]. Segmenting the Active Sport Tourist Market: A LifeSpan Perspective. Journal of Vacation Marketing, 4 , 1,52-64.

[6] Kaplanidou, K., \&Gibson, H. J. (2010). Predicting behavioral intentions of active event sport tourists: The case of a small-scale recurring sports event. Journal of Sport \& Tourism, 15, 2, $163-179$.

[7] Gibson, H.J., Kaplanidou, K., \& Kang, S.J. (2012). Small-scale event sport tourism: A case study in sustainable tourism. Sport Management Review, $15,160-170$.

[8] Završene utrke: Stotinka Timing. (2019), available at: https://www.stotinka.hr/hrv/zavrsene_utrke?mo nth_year=042019 (13.12.2020.)

[9] Bell, S., Tyrväinen, L., Sievänen, I., Pröbstl, U., \& Simpson, M. (2007). Outdoor Recreation and Nature Tourism: A European Perspective. Living Reviews in Landscape Research, 1, 2,146.

[10] Green, B. C. [2001). Leveraging Subculture and Identity to Promote Sport Events. Sport Management Review, 4, 1,1-19.

[11] Snelgrove, R., \& Wood, L. [2010]. Attracting and Leveraging Visitors at a Charity Cycling Event. Journal of Sport \&Tourism, 15, 4, 269-285.

[12] Duglio, S. \& Beltramo, R. [2017). Estimating the Economic Impacts of a Small-Scale Sport Tourism Event: The Case of the Italo-Swiss Mountain Trail Collon Trek. Sustainability, $9,3,343$. 
[13] Daniels, M. J., \& Norman, W. C. [2003]. Estimating the economic impacts of seven regular sport tourism events. Journal of Sport Tourism, 8, 4, 214-222.

[14] Gibson, H., Mclntyre, S., MacKay, S. \& Riddington, G. [2005). The Economic Impact of Sports, Sporting Events, and Sports Tourism in the UK: The DREAMTM Model. European Sport Management Quarterly, 5, 3, 321-332.

[15] Weed, M.E. [2004, September]. „Sports Tourism Research 2000-2003: A Systematic Review of Knowledge and a Meta-Evaluation of Method" paper presented at Twelfth European Association of Sport Management Congress, Ghent, Belgium.

[16] Weber, K. (2001]. Outdoor Adventure Tourism: A Review of Research Approaches. Annals of Tourism Research, 28, 2, 360-377.

[17] Hirschman, E.C., \& Holbrook, M.B.(1992]. Postmodern Consumer Research: The Study of Consumption as Text, Sage, Newbury Park, CA

[18] Kleine III, R. E., Kleine, S. S., \& Kernan, J. B. (1993). Mundane Consumption and the Self: A Social Identity Perspective. Journal of Consumer Psychology, 2, 3, 209-235.

[19] Deery, M., Jago, L., \& Fredline, L. (2004). Sport tourism or event tourism: Are they one and the same?. Journal of Sport \& Tourism, 9, 3, 235 -245.

[20] Priporas, C. V., Vassiliadis, C. A., Stylos, N., \& Fotiadis, A. K. (2018). The effect of sport tourists' travel style, destination and event choices, and motivation on their involvement in small-scale sports events. Event Management, 22, 5, 745-765.

[21] Halpenny, E. A., Kulczycki, C., \& Moghimehfar, F. (2016). Factors effecting destination and event Ioyalty: examining the sustainability of a recurrent small-scale running event at Banff National Park, Journal of Sport \&Jourism, 20, 3-4, 233-262.

[22] Beaton, A. A, Funk, D. C., Ridinger, L., \& Jordan, J. (2011). Sport Involvement: A conceptual and empirical analysis. Sport Management Review, 14, 2,126-140.

[23] Greppel, P., Wegner, M., \& Schóler, J. [2016]. Achievement motive and sport participation, Psychology of Sport and Exercise, 27, 93-100.

[24] Kerr, J. H., \& Mackenzie, S. H. (2012]. Multiple motives for participating in adventure sports. Psychology of Sport and Exercise, 13, 5, 649-657.

[25] Perič, M., Đurkin, J., \& Vitezič, V. [2018). Active Event Sport Tourism Experience: The Role of the Natural Environment, Safety and Security in Event Business Models. International Journal of Sustainable Development and Planning, 13, 5, 758772.

[26] Hallmann, K., \& Harms, G. [2012). Determinants of volunteer motivation and their impact on future voluntary engagement: A comparison of volunteers' motivation at sport events in equestrian and handball. International Journal of Event and Festival Management, 3, 3, 272-291.

[27] Ritchie, B. W., Tkaczynski, A., \& Faulks, P. [2010). Understanding the motivation and travel behavior of cycle tourists using involvement profiles. Journal of Travel \& Tourism Marketing, 27, 4, 409-425.

[28] Perrin-Malterre, C. [2018], Tourism diversification process around trail running in the Pays of Allevard (Isère), Journal of Sport \&Tourism, 22, 1,67-82.

[29] Ng, S.-L., Leung, Y.-F., Cheung, S.-Y. and Fang, W. (2018), Land degradation effects initiated by trail 
running events in an urban protected area of Hong Kong, Land Degradation and Development, 29, 3, 422-432.

[30] Ribet, S., \&Brander, L. M. (2020). Willingness to pay of trail runners for sustainable country park use in Hong Kong. Journal of Outdoor Recreation and Tourism, 31, 100320.

[31] Perić, M., Dragičević, D. \& Škorić, S. [2019]. Determinants of active sport event tourists' expenditure - the case of mountain bikers and trail runners. Journal of Sport \& Tourism, 23, 1, 19-39.

[32] Nagai, M. and Take, M. (2018), Relationship between motivation for participation in trail running competition and competition distance, Journal of The Japanese Institute of Landscape Architecture, 81, 5, 533-536.

[33] Getz, D. and McConnell, A. [2011], Serious sport tourism and event travel careers, Journal of Sport Management, 25, 4, 326-338.

[34] Hodeck, A., Kuehnast, J., \& Wohlfart, 0. (2018). Comparing Iwo Types of Nature Sport [Event] Tourists in Germany Based on Travel Motivation and Behaviour-the Case of Ski Tourers vs. Trail Runners. Proceedings of The 26th European sport Management Conference Managing sport in a Changing Europe, pp. 203-205, Malmo, Department of Sport Sciences, University of Malmo, Malmo

[35] Pike, S. [2008). Destination Marketing: An Integral Marketing Communication Approach, Butterworth Heinemann, Amsterdam

[36] Dolnicar, S., \& Leisch, F. (2003). Winter tourist segments in Austria: Identifying stable vacation styles using bagged clustering techniques. Journal of Travel Research, 41, 3, 281-292.
[37] Dolnicar, S., \&Fluker, M. [2003). Behavioural market segments among surf tourists: Investigating past destination choice. Journal of Sport Tourism, 8, 3, 186-196.

[38] Reynolds, L., \& Hritz, N. M. (2012). Surfing as adventure travel: Motivations and lifestyles. Journal of Tourism Insights, 3, 1, 14-23.

[39] Dickson, I. J., \& Dolnicar, S. (2006). Ascending Mt Kosciuszko: An exploration of motivational patterns. CD Proceedings of the 15th International Research Conference of the Council for Australian University Tourism and Hospitality Education (CAUTHE 2006): To the City and Beyond, 1030, available at: http://ro.uow.edu.au/commpapers/75 [20.05.2021.]

[40] Woratschek, H., Hannich, F. M., \& Ritchie, B. [2007]. Motivations of sport tourists - an empirical analysis of several European rock climbing regions, available at: http://www.fiwi.unibayreuth.de/de/ download/WP_02-07.pdf [06.05.2021.]

[41] Boukas, N., \&ziakas, V. [2013]. Golf tourist motivation and sustainable development: $A$ marketing management approach for promoting responsible Golf tourism in cyprus, available at: http://wWW.

academia.edu/3568662/Golf_Tourist_Motivation_a nd_Sustainable_Development_A_Marketing_ Management_Approach_for_Promoting_Responsib le_Golf_Tourism_in_Cyprus [04.05.2021.]

[42] Green, B. C., \& Tanabe, L. [1998]. Marathons, Motive, and Marketing: Segmentation Strategies and the Gold Coast Marathon, Proceedings of North 
American Society for Sport Management Annual Conference, Buffalo, NY.

[43] Hungenberg, E. M. [2015]. An Examination of Motives Underlying Active Sport Tourist Behavior: A Market Segmentation Approach. [Doctoral Dissertation, University of Northern Colorado]. Digital UNC.

[44] Shipway, R., \& Jones, I. (2007). Running away from Home: Understanding Visitor Experiences and Behavior at Sport Tourism Events. International Journal of Tourism Research, 9, 5, 373-383.

[45] Kim, K., Hallab, L., \& Smith, M. [2008). Tourism economic impacts: The case of equine camping in southern Illinois. Advances in hospitality and leisure, 4, 245-260.

[46] Murphy, M., \& Bernal, M. (2008). „The impact of surfing on the local economy of Mundaka, Spain. Davenport, CA: Save the Waves Coalition" , available at:

http://wWw.limmatwave.com/Presse/Surfonomic sstudieMundaka.pdf (20.05.2021.) 